\author{
I.E. Stas ${ }^{1}$, S.S. Pavlova ${ }^{2 *}$ \\ ${ }^{l}$ Altai State University, Barnaul, Russia, \\ ${ }^{2}$ Yugra State University, Khanty-Mansiysk, Russia \\ (Corresponding author`s e-mail: pavlova_ss@mail.ru)
}

\title{
Effect of ultrahigh-frequency electromagnetic field on the properties of associated liquids
}

\begin{abstract}
The influence of the electromagnetic field on the refractive index, evaporation rate and surface tension of water, propanol-1 and pentanol-1 solutions have been studied. It was shown that the properties of these liquids depend on the field frequency and the time of exposure. The action of the field on the structure of water and alcohols is selective; changes in their properties are due to frequencies that are individual for each liquid. Both deceleration and acceleration of the alcohols evaporation occurs depending on the frequency of the electromagnetic field. Evaporation of the field exposed water is slowing down at all the studied frequency range. There is an increase in the surface tension for water and pentanol, and a decrease for propanol. The properties of alcohols return to their initial values, and the properties of the water remain unchanged after the termination of the field action. Thermodynamic functions of surface water and propanol-1 have been calculated on the basis of the temperature dependence of the surface tension. It has been demonstrated that the total internal energy of the surface increases for water and reduces or propanol-1. This indicates the strengthening of the structure in an aqueous solutions and a weakening of intermolecular interaction in the propanol-1 medium.
\end{abstract}

Keywords: water, propanol-1, pentanol-1, electromagnetic field, frequency, refractive index, evaporation rate, surface tension.

\section{Introduction}

Many studies demonstrate that water is able to react to any external influence. This fact is revealed in the change of its bulk and surface properties. There is an annual increase in publications devoted to the study of response of liquid water on the influence of physical fields of different nature [1-5]. Previous studies have shown that water treatment with an electromagnetic field of low-intensity of radio frequency leads to an increase in its electrical conductivity, surface tension and heat of evaporation. A decrease in the rate of evaporation and adhesion to a solid surface has been observed. These effects are revealed only at certain frequencies of the field (the range of 30-200 MHz has been studied) and rise up to a specific limit with increasing of exposure time. It has been also found that the changed properties of water do not return to their original values, and were kept for a long time; for example, the observations were carried out during the year [6-8]. The experimentally observed changes in the properties of water are associated with the rearrangement of the supramolecular organization of water due to the presence of hydrogen bonds [9-11].

However, water is not the only liquid whose molecules are hydrogen-bonded. Hydrogen bonds are also formed between alcohol molecules, carboxylic acids, esters, mercaptans, etc in a liquid state [12]. Monobasic alcohol and water differ significantly in the energy of hydrogen bonds. According to [13], the hydrogen bond energy for water is 18.8 , while for methanol and ethanol is $25.9 \mathrm{~kJ} \mathrm{~mol}^{-1}$. Considering that one water molecule has two hydrogen bonds, while alcohols have only one, it becomes obvious that the stability of the water structure is much higher.

Alcohol molecule is considered as a water molecule with one hydrogen atom substituted with a hydrocarbon radical [14]. The fraction of association, the composition and the form of associates depend on various factors. The association fraction of the alcohols decreases with increase of alcohols molecular weight. The so-called weighting effect is typical to them [14-16]. Its physical existence is associated with a weakening of hydrogen bonds due to steric factor and thermal vibrations of the particles. The rise in temperature and the addition of some non-polar substances act in the same direction as the weighting effect. The effect of weighting is also revealed in the fact that their structure becomes denser with an increase in the alcohols molecular weight [14].

\footnotetext{
${ }^{*}$ Corresponding author
} 
It can be expected that the field action can change the structure of the alcohols, which should reveal in the change of their bulk and surface properties.

The aim of the work is to determine the changes in physical and chemical properties of propanol-1 and pentanol-1 and water, caused by the intermolecular interaction, as a result of exposure of electromagnetic field.

Research in this area has expanded the understanding of the nature of the interaction of electromagnetic field with the matter. Research in this area has expanded the understanding of the nature of the interaction of an electromagnetic field with matter.

\section{Experimental}

Propanol-1 (GOST 6006-78), pentanol-1 (chemically pure, TU 2632-106-4449379-07 at a concentration not less than $5 \%$ and the water purified by using membrane distillation DME-1/B have been used. Specific conductivity of the water was $1.1 \mu \mathrm{s} / \mathrm{cm}$.

Irradiation of alcohols and water was carried out in a contactless manner using a GZ-19A generator with a variable frequency in the range of 30-200 MHz. Generator power output was 1 watt. The voltage on the HF electrodes was 20-22 V. Cell of a capacitive type with a volume of $20 \mathrm{ml}$ with the axially spaced electrodes has been used in the work.

The refractive index was determined using refractometer URL No. 77-2549 (accuracy \pm 0.0001 ).

Determination of surface tension was carried out by weighing of drops (variety of stalagmometric method). Weighting of 50 drops leaked out of stalagmometry, was carried out on an analytical balance BM153M-II with an accuracy of $\pm 0.001 \mathrm{~g}$. Deionized water has been used as the standard liquid. Thermostat TJ-TB-01 was used when studying the temperature dependence of surface tension of liquids. The temperature accuracy was $\pm 0.10^{\circ} \mathrm{C}$.

The evaporation of alcohol and water was performed from plastic Petri dishes (surface area of the liquid $\left.\mathrm{S}=50 \mathrm{~cm}^{2}\right)$ at room temperature, $\left(22^{\circ} \mathrm{C}\right)$ for an hour, recording the mass loss of the dishes with the liquid every 10 minutes with the help of analytical balance BM153M-II. The experiment with irradiated and nonirradiated alcohols or water was performed simultaneously to ensure the same external conditions (atmospheric pressure, humidity and air temperature). Kinetic curves were plotted in the coordinates of the mass of evaporated liquid $(\mathrm{m})$ vs time $(\mathrm{t})$ based on the obtained data. The evaporation rate was determined from the slope of the kinetic curve.

\section{Results and Discussion}

Studies have shown that the refractive index (n) of propanol as a result of exposure to an electromagnetic field (EMF) practically does not change (the increase does not exceed $0.01 \%$ ). The increase in $n$ is more signified for pentanol (0.03-0.06\%) (Table 1).

T a b l e 1

Refractive index $n$ of pentanol-1 exposed by electromagnetic field of different frequencies $\left(t_{\text {irr. }}=60\right.$ min, $\left.T=295 \mathrm{~K}\right)$

\begin{tabular}{|c|c|c|c|c|c|}
\hline$f, \mathrm{MHz}$ & 0 & 50 & 70 & 90 & 100 \\
\hline $\mathrm{n}$ & $1.4096 \pm 0.0002$ & $1.4096 \pm 0.0001$ & $1.4100 \pm 0.0001$ & $1.4104 \pm 0.0002$ & $1.4100 \pm 0.0001$ \\
\hline$\Delta \mathrm{n}, \%$ & - & - & 0.03 & 0.06 & 0.04 \\
\hline
\end{tabular}

The increase in refractive index is observed only at the 3 frequencies EMF: 70, 90 and $100 \mathrm{MHz}$. The effect for water is revealed at frequencies exceeding $100 \mathrm{MHz}$, and much higher $-0.10-0.15 \%$ (Table 2).

Table 2

Refractive index of water exposed by electromagnetic field of different frequencies $\left(t_{\text {irr. }}=60 \mathrm{~min}, \mathrm{~T}=\mathbf{2 9 5} \mathrm{K}\right)$

\begin{tabular}{|c|c|c|c|c|c|c|}
\hline$f, \mathrm{MHz}$ & 0 & 100 & 130 & 140 & 150 & 170 \\
\hline $\mathrm{n}$ & $1.3330 \pm 0.0002$ & $1.3338 \pm 0.0003$ & $1.3345 \pm 0.0002$ & $1.3344 \pm 0.0002$ & $1.3343 \pm 0.0003$ & $1.3350 \pm 0.0003$ \\
\hline$\Delta \mathrm{n}, \%$ & - & 0.06 & 0.11 & 0.10 & 0.10 & 0.15 \\
\hline
\end{tabular}


The refractive index of a liquid is related to its density by empirical relation:

$$
n=1+a \rho,
$$

where $n-$ is the refractive index; $a-$ is an empirical coefficient; $\rho-$ is the fluid density [17].

Therefore, it can be argued that the increase in $n$ indicates a certain increase in the density of pentanol and water, which is most typical for water. And the density of a liquid is directly related to their structural organization.

The rate of evaporation is also determined by the force of intermolecular interactions in the liquid. The evaporation rate of irradiated and non-irradiated alcohols with the free surface at $\mathrm{T}=295 \mathrm{~K}$ has been studied. The kinetic curves are presented in Figures 1 and 2. The evaporation rate was determined from the slope of the curves based on the mass of the evaporated alcohol $(\mathrm{m})$ vs the time as:

$$
U=d m / d t \cdot S \text {, }
$$

where $d m$ - is the mass of the evaporated alcohol; $d t-$ is the evaporation time; $S$ - is the surface area of the alcohol.

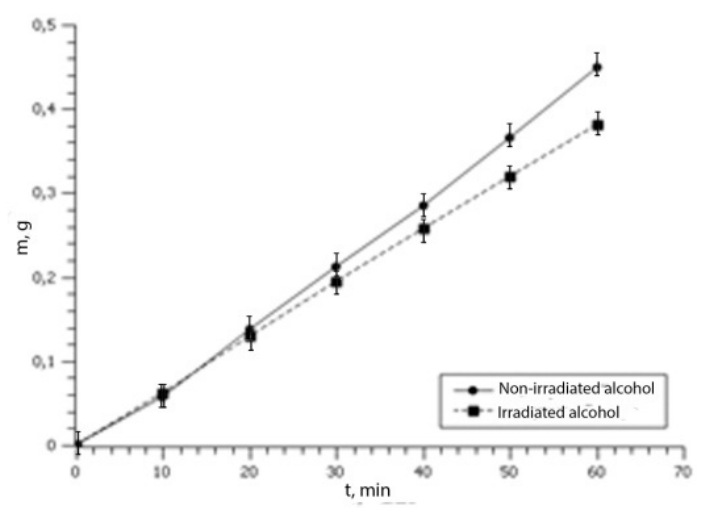

$a$

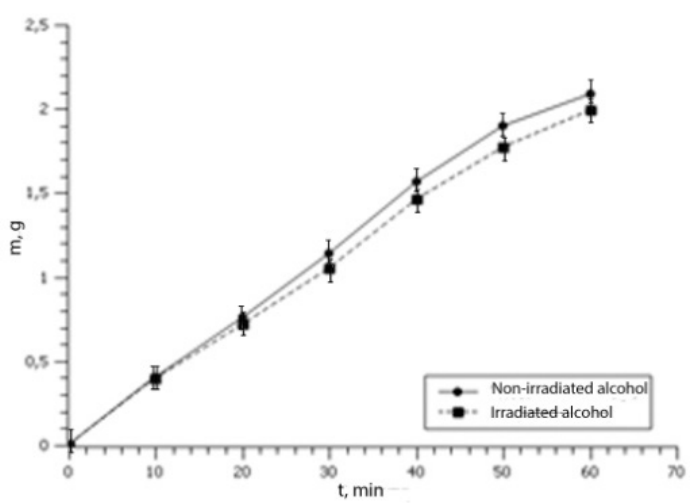

$b$

$a-\operatorname{pentanol} ; b-\operatorname{propanol}(f=70 \mathrm{MHz}, \mathrm{T}=295 \mathrm{~K})$

Figure 1. Kinetic curves of evaporation

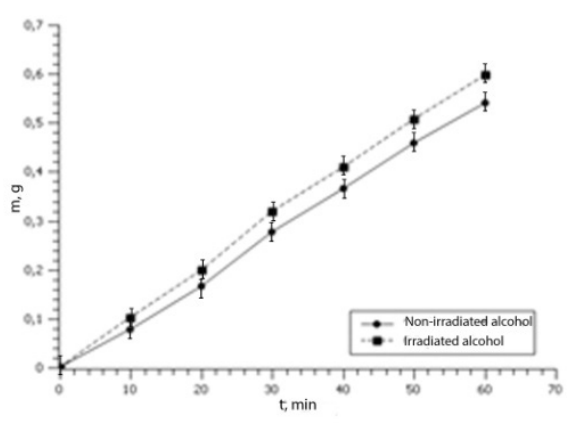

$a$

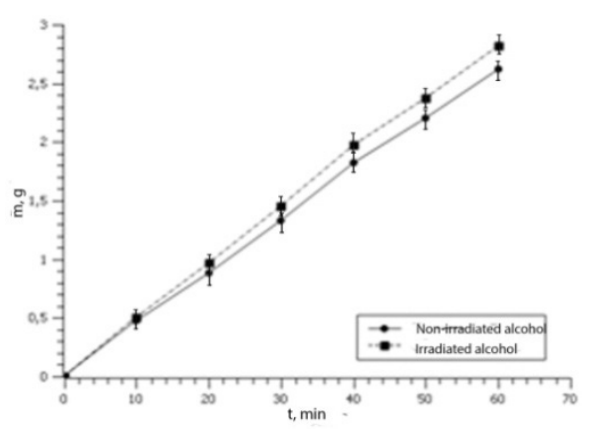

$b$

$a$ - pentanol; $b-\operatorname{propanol}(f=90 \mathrm{MHz}, \mathrm{T}=295 \mathrm{~K})$

Figure 2. Kinetic curves of evaporation

The values of relative evaporation rate, irradiated by the field of various frequencies $\left(U_{\text {rel. }}=U_{\text {irr. }} / U_{\text {non-irr. }}\right.$, where $U_{\text {irr }}$ and $U_{\text {non-irr }}$ - are evaporation rates of irradiated and non-irradiated alcohols, respectively) are presented in Tables 3 and 4.

Relative evaporation rates of non-irradiated and irradiated with an electromagnetic field of different frequencies propanol $(T=295 \mathrm{~K})$

\begin{tabular}{|l|c|c|c|c|}
\hline Frequency $f, \mathrm{MHz}$ & 0 & 70 & 80 & 90 \\
\hline Relative rate $\mathrm{U}_{\text {irr. }} / \mathrm{U}_{\text {non-irr }}$ & $1.00 \pm 0.01$ & $1.27 \pm 0.01$ & $1.24 \pm 0.01$ & $1.08 \pm 0.02$ \\
\hline
\end{tabular}


Relative evaporation rates of non-irradiated and irradiated with an electromagnetic field of different frequencies pentanol $(T=295 \mathrm{~K})$

\begin{tabular}{|l|c|c|c|c|}
\hline Frequency $f, \mathrm{MHz}$ & 0 & 50 & 70 & 90 \\
\hline Relative rate $\mathrm{U}_{\text {irr. }} / \mathrm{U}_{\text {non-irr }}$ & $1.00 \pm 0.02$ & $1.15 \pm 0.02$ & $0.85 \pm 0.01$ & $1.10 \pm 0.03$ \\
\hline
\end{tabular}

The rate of evaporation of the irradiated alcohols differs markedly from the rate of evaporation of nonirradiated alcohol, both upward and downward. Pentanol-1 evaporates at a maximum rate after exposure to EMF with a frequency of $50 \mathrm{MHz}$, and propanol-1 - after exposure to a field with a frequency of 70-80 MHz. Reducing the rate of evaporation is observed for the pentanol at a frequency of $70 \mathrm{MHz}$.

Experiments have shown a slowdown in water evaporation as a result of exposure to EMF in the frequency range of 120 and $190 \mathrm{MHz}$. The maximum effect is achieved for EMF frequencies of 130 and $170 \mathrm{MHz}$ and is approximately $20 \%$, as evidenced by the reduced mass of fluid evaporated in two hours (Table 5).

Table 5

\section{Mass of evaporated water irradiated with an electromagnetic field of different frequencies $\left(T=295 \mathrm{~K}, \mathrm{t}_{\mathrm{irr}}=\mathbf{2} \mathrm{h}\right)$}

\begin{tabular}{|c|c|c|}
\hline$f, \mathrm{MHz}$ & Mass of evaporated water, $\mathrm{g}$ & $\Delta \mathrm{m}, \%$ \\
\hline 0 & $1.68 \pm 0.05$ & - \\
\hline 130 & $1.35 \pm 0.04$ & 19.6 \\
\hline 140 & $1.50 \pm 0.05$ & 10.7 \\
\hline 150 & $1.37 \pm 0.02$ & 18.4 \\
\hline 160 & $1.39 \pm 0.07$ & 17.3 \\
\hline 170 & $1.35 \pm 0.05$ & 19.6 \\
\hline 190 & $1.48 \pm 0.05$ & 11.9 \\
\hline
\end{tabular}

The irradiation time also influences affects the magnitude of the effect in addition to EMF frequency. Experiments on exposure of water by a field of the particular frequencies $(130,150$ and $170 \mathrm{MHz})$ for different periods of time (from 30 minutes to 3 hours) were carried out.

It has been shown that 30 minutes is enough for maximum effect. When 2- and 3-hour effects of the field, evaporation slowing was exactly the same as at 30 minutes. Slower evaporation of water exposed to the electromagnetic influence, may be a consequence of strengthening of intermolecular interactions. Confirmation of this hypothesis is the previously detected increase in the boiling temperature and evaporation heat of water, which also depend on the energy of intermolecular interactions [7].

The surface tension of liquids also depends on intermolecular interactions, since it is determined by the work of the molecules coming out from the phase volume to the surface. Measurement of the surface tension of pentanol demonstrated its significant increase as a result of exposure to EMF at only three frequencies: 50, 70 and $90 \mathrm{MHz}$ (Fig. 3). The maximum surface tension increases by $3.5 \%$ at a frequency of $50 \mathrm{MHz}$ (for non-irradiated alcohol $\sigma=25.6 \pm 0.1 \mathrm{MJ} / \mathrm{m}^{2}$ ).

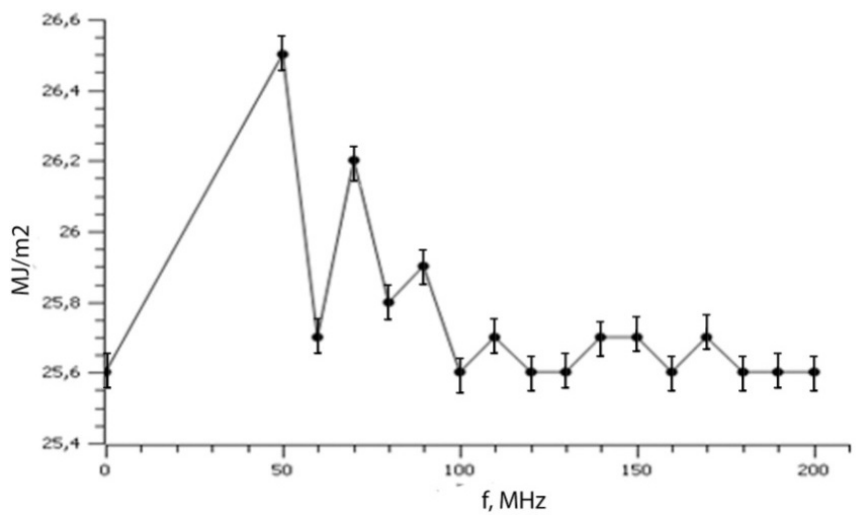

Figure 3. Dependence of surface tension of pentanol on the frequency of the electromagnetic field $(\mathrm{T}=298 \mathrm{~K})$ 
Since all previous studies have shown an increase in the efficiency of field effects with an increase in the exposure time, the time dependence of the changes in surface tension during irradiation of pentanol to field of frequency 50.70 and $90 \mathrm{MHz}$ was studied. Figure 4 shows the kinetic curves for two frequencies of 50 and $70 \mathrm{MHz}$.

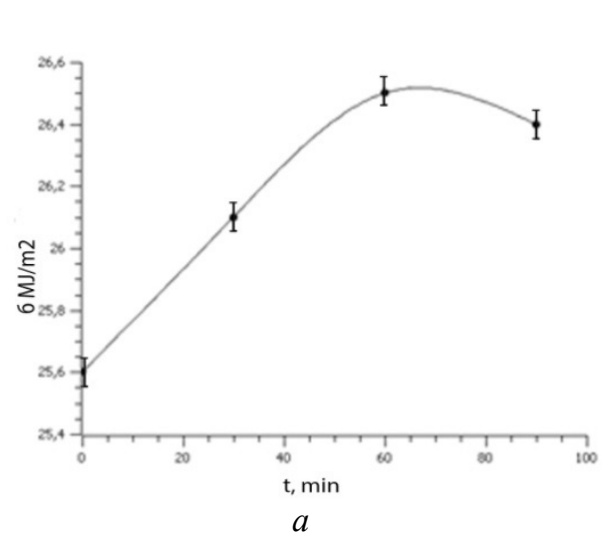

$$
f=50 \mathrm{MHz}
$$

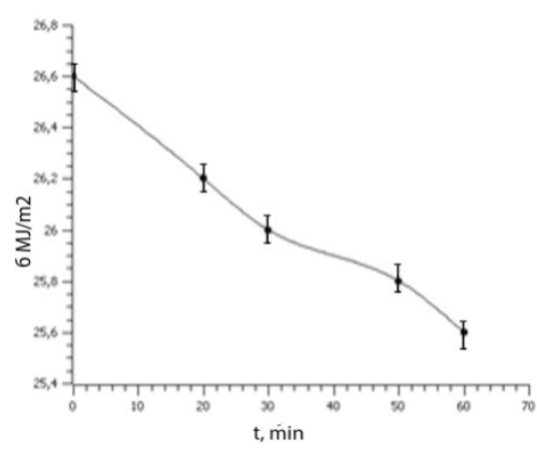

$b$

$$
f=70 \mathrm{MHz}
$$

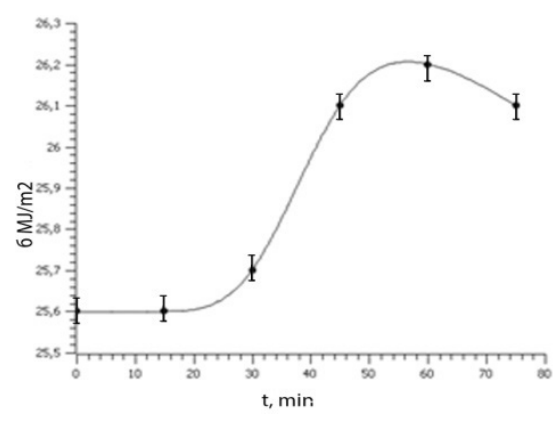

$a$

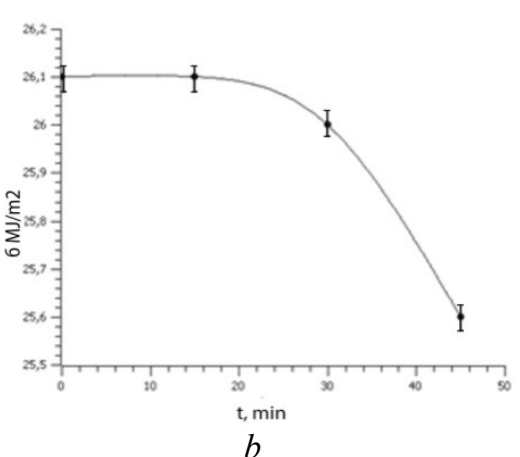

$a-$ on the time of irradiation; $b-$ on time after the termination of radiation $(\mathrm{T}=298 \mathrm{~K})$

Figure 4. Dependence of surface tension of pentanol

It was detected the intensification effect by increasing the exposure time to 1 hour. Further exposure led to a slight decrease in surface tension. It is the most evident at the frequency of $90 \mathrm{MHz}$. A gradual approach of the measured value to the initial amount was observed after the termination of the EMF emission (Fig. 4b). It should be noted that the relaxation of surface tension began due to the ongoing exposure of alcohol. The relaxation time ranged from 45 minutes to 1 hour depending on the field frequency.

Strengthening of the effect and relaxation occurred simultaneously when pentanol was irradiated to a field with a frequency of $50 \mathrm{MHz}$. At the same time, the relaxation of the properties to the initial value occurred faster than the increase effect when it was exposed to fields with a frequency of 70 and $90 \mathrm{MHz}$ (Table 6).

Surface tension, increase and relaxation times for irradiated pentanol $(\mathrm{T}=\mathbf{2 9 8} \mathrm{K})$

\begin{tabular}{|l|c|c|c|}
\hline$f, \mathrm{MHz}$ & 50 & 70 & 90 \\
\hline$\sigma, \mathrm{MJ} / \mathrm{M}^{2}$ & $26.5 \pm 0.2$ & $26.2 \pm 0.1$ & $25.9 \pm 0.1$ \\
\hline$\Delta \sigma, \%$ & 3.5 & 2.6 & 1.4 \\
\hline Increase time $\sigma$, min. & 60 & 60 & 60 \\
\hline Relaxation time $\sigma$, min. & 60 & 45 & 45 \\
\hline
\end{tabular}

Similar studies have been carried out for propanol-1. In this case, the surface tension change was well signified only for the frequencies of 70 and $80 \mathrm{MHz}$, and there was not an increase but there was a decrease by $10.9 \%$ and $3.9 \%$ respectively (Fig. 5 ). 


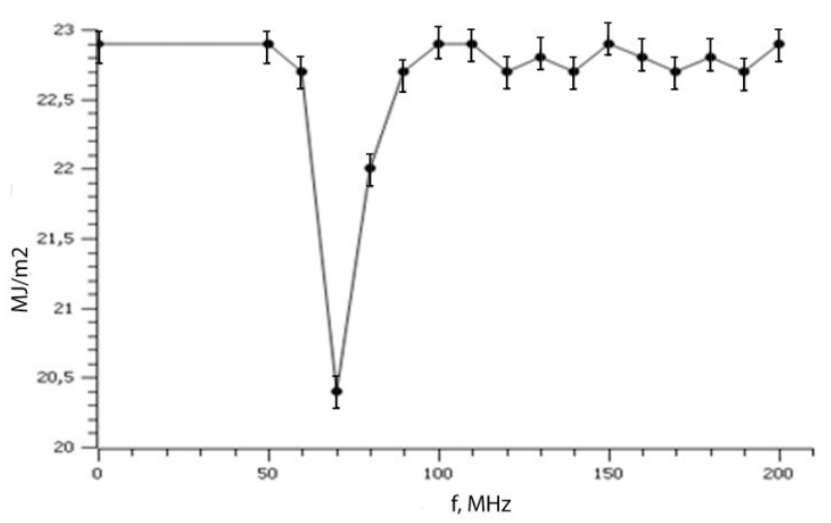

Figure 5. Dependence of surface tension of propanol on the frequency of the electromagnetic field $(\mathrm{T}=298 \mathrm{~K})$

The maximum effect in this case was also achieved with an exposure time, of 1 hour. After the termination of the field effects the surface tension of propanol returns to its initial value in 40 minutes (Fig. 6). The presence of relaxation processes proves that the results obtained are not associated with the error in determination of the surface tension.

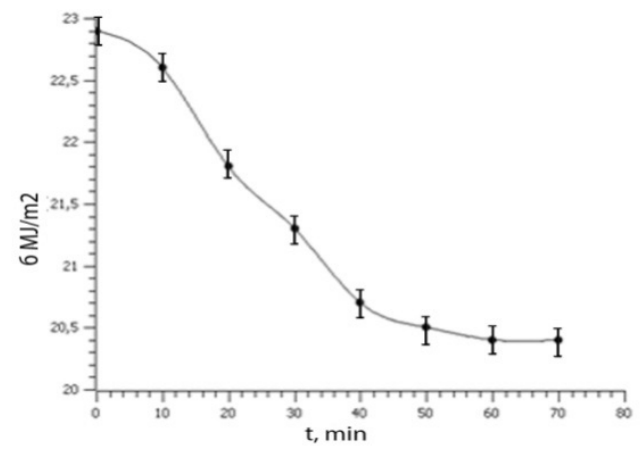

$a$

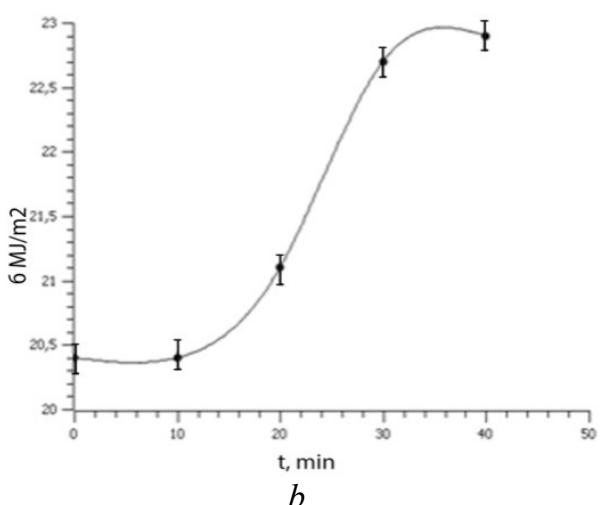

$a$ - on the time of irradiation; $b-$ on time after termination of irradiation $(f=70 \mathrm{MHz})$

Figure 6. Dependence of surface tension of propanol

The EMF exposure on water, as well as on the pentanol led to an increase in surface tension, mainly at frequencies of 130 and $170 \mathrm{MHz}$. The maximum effect is achieved within 1 hour (Table 7). After termination of irradiation the surface tension of water decreased for 3 months, during which we conducted observations.

Ta b l e 7

\section{Change of surface tension of water depending on the time of exposure to electromagnetic fields} $\left(\sigma_{0}=72.8 \mathrm{MJ} / \mathrm{m}^{2}, T=295 \mathrm{~K}\right)$

\begin{tabular}{|c|c|c|c|c|c|}
\hline $\mathrm{t}, \mathrm{min}$ & 30 & 60 & 90 & 120 & 150 \\
\hline $\begin{array}{c}\sigma, \mathrm{MJ} / \mathrm{m}^{2}, \\
f=130 \mathrm{MHz}\end{array}$ & $74.7 \pm 0.7$ & $82.2 \pm 1.1$ & $82.3 \pm 0.9$ & $82.2 \pm 0.7$ & $82.2 \pm 1.0$ \\
\hline $\begin{array}{c}\sigma, \mathrm{MJ} / \mathrm{m}^{2}, \\
f=170 \mathrm{MHz}\end{array}$ & $77.4 \pm 0.8$ & $82.5 \pm 1.0$ & $82.5 \pm 1.0$ & $82.5 \pm 0.9$ & $82.5 \pm 1.1$ \\
\hline
\end{tabular}

It is known that the surface tension of the liquid reduces with increasing temperature. This occurs on the one hand, due to the convergence of the force fields of coexisting phases (liquid - vapor), and, on the other hand, due to the weakening of the intermolecular interactions, as a result of an increase in the intensity of the thermal motion of molecules [18]. Conducted studies have shown that the surface tension of water activated by EMF also decreases with increasing temperature, but to a greater extent compared to non-activated (Table 8). Temperature coefficient $\mathrm{d} \sigma / \mathrm{dT}$ for non-activated water is $(-0.154) \mathrm{MJ} / \mathrm{m}^{2} \cdot \mathrm{K}$ [19]. After its electro- 
magnetic treatment the linear character of the dependence of surface tension on temperature is kept, however, the temperature coefficient increases sharply $d \sigma / d T=-0.251 \mathrm{MJ} / \mathrm{m}^{2} \cdot \mathrm{K}(130$ and $170 \mathrm{MHz})$. For irradiated propanol temperature coefficient of surface tension has a lower value $d \sigma / d T=-0.05-0.06 \mathrm{MJ} / \mathrm{m}^{2} \cdot \mathrm{K} \mathrm{com}$ pared to non-irradiated, for which $d \sigma / d T=-0.08 \mathrm{MJ} / \mathrm{m}^{2} \cdot \mathrm{K}[19]$.

The thermodynamic functions of the surface layer (internal energy $\left(U_{s}\right)$, entropy $\left(S_{s}\right)$ and heat of unit of area formation $\left(q_{s}\right)$ ) were calculated based on the temperature dependence of the surface tension of water and propanol. The calculation was performed using the equations of Gibbs-Helmholtz [18]:

$$
\begin{gathered}
U_{s}=\sigma-T \cdot(d \sigma / d T)_{p} ; \\
U_{s}=\sigma+q_{s} ; \\
S_{s}=-(d \sigma / d T)_{p} .
\end{gathered}
$$

The results of the calculations are presented in Tables 8 and 9.

Ta a le 8

Thermodynamic functions of the surface layer of non-activated and activated water (170 MHz) in the temperature range $289-300 \mathrm{~K}$

\begin{tabular}{|c|c|c|c|c|c|c|}
\hline $\mathrm{T}, \mathrm{K}$ & 289 & 293 & 295 & 296 & 297 & 300 \\
\hline \multicolumn{7}{|c|}{ non-activated water } \\
\hline$\sigma, \mathrm{mJ} / \mathrm{m}^{2}$ & 73.3 & 72.7 & 72.5 & 72.3 & 72.1 & 71.6 \\
\hline$q_{s}, \mathrm{~mJ} / \mathrm{m}^{2}$ & 43.6 & 44.3 & 44.5 & 44.7 & 44.8 & 45.3 \\
\hline$U_{s}, \mathrm{~mJ} / \mathrm{m}^{2}$ & 117 & 116 & 117 & 117 & 117 & 117 \\
\hline \multicolumn{7}{|c|}{ activated water $(170 \mathrm{MHz})$} \\
\hline$\sigma, \mathrm{mJ} / \mathrm{m}^{2}$ & 82.2 & 77.1 & 76.2 & 73.2 & 72.2 & 69.2 \\
\hline$q_{s}, \mathrm{~mJ} / \mathrm{m}^{2}$ & 72.5 & 73.5 & 74.3 & 74.3 & 74.5 & 75.3 \\
\hline$U_{s}, \mathrm{~mJ} / \mathrm{m}^{2}$ & 155 & 151 & 150 & 147 & 146 & 144 \\
\hline
\end{tabular}

Thermodynamic functions of the surface layer of water activated by electromagnetic field of different frequencies

\begin{tabular}{|c|c|c|c|c|c|}
\hline$f, \mathrm{MHz}$ & 0 & 130 & 160 & 165 & 170 \\
\hline$U_{s}, \mathrm{~mJ} / \mathrm{m}^{2}$ & 117 & $153-145$ & 138 & 129 & $155-144$ \\
\hline$q_{s}, \mathrm{~mJ} / \mathrm{m}^{2}$ & $43.6-45.3$ & $71.5-74.8$ & $70.4-75.0$ & $67.0-68.4$ & $72.5-75.3$ \\
\hline$S_{s}, \mathrm{~mJ} / \mathrm{m}^{2}$ & 0.154 & 0.251 & 0.241 & 0.160 & 0.251 \\
\hline
\end{tabular}

Similar calculations have been carried out for propanol (Table 10).

$\mathrm{Tab}$ e 10

Thermodynamic functions of the surface layer of propanol

\begin{tabular}{|c|c|c|c|c|c|c|c|c|c|}
\hline \multirow{2}{*}{ Thermodynamic function } & \multicolumn{3}{|c|}{ Unirradiated propanol } & \multicolumn{5}{|c|}{ Irradiated propanol } \\
\cline { 3 - 10 } & \multicolumn{3}{|c|}{$(f=70 \mathrm{MHz})$} & \multicolumn{3}{|c|}{$(f=80 \mathrm{MHz})$} \\
\hline $\mathrm{T}, \mathrm{K}$ & 276 & 282 & 288 & 276 & 282 & 288 & 276 & 282 & 288 \\
\hline$\sigma, \mathrm{mJ} / \mathrm{m}^{2}$ & 24.4 & 23.9 & 23.4 & 23.9 & 23.4 & 23.3 & 24.2 & 23.7 & 23.4 \\
\hline$U_{s}, \mathrm{~J} / \mathrm{m}^{2}$ & 46.5 & 46.5 & 46.4 & 37.7 & 37.5 & 37.7 & 40.8 & 40.6 & 40.6 \\
\hline$q_{s}, \mathrm{~mJ} / \mathrm{m}^{2}$ & 22.1 & 22.6 & 23.0 & 13.8 & 14.1 & 14.4 & 16.6 & 16.9 & 17.2 \\
\hline$S_{s,}, \mathrm{~mJ} / \mathrm{m}^{2}$ & 0.08 & 0.08 & 0.08 & 0.05 & 0.05 & 0.05 & 0.06 & 0.06 & 0.06 \\
\hline
\end{tabular}

As can be seen from Table 10, the heat of formation of the surface as an entropy component makes a significant contribution to the total surface energy. It is about half of the total surface energy for many organic substances, [18]. This is due to the fact that when molecules move from one liquid volume to its surface, bonds are broken and the substance is in a state close to the vapor phase, with higher entropy on the surface. Values $U_{s}, q_{s}$, and $\mathrm{S}_{\mathrm{s}}$ of irradiated propanol-1 are significantly lower than the corresponding values for nonirradiated alcohol. Therefore, it can be concluded that the intermolecular interaction is weakened as a result of field exposure. On the contrary, the total surface energy of water increases by both enthalpy and entropy factors (Tables 8,9). This indicates the opposite effect of the field on water, that is, on the strengthening of its structure. 


\section{Conclusions}

Thus, the studies carried out have shown that alcohol, as well as water, is capable to absorb the energy of the electromagnetic field, changing its physical properties, which can be a consequence of changes in the supramolecular organization of these liquids. The absorption of electromagnetic energy is selective. Each liquid corresponds to a specific set of frequencies, where there are change in surface tension, refractive index and evaporation rate. The maximum change in properties is observed at $70 \mathrm{MHz}$ for propanol- 1 and at 50 $\mathrm{MHz}$ for pentanol-1. The extreme frequencies for water are 130 and $170 \mathrm{MHz}$ and they differ significantly from those values. The magnitude of the field response at these frequencies is markedly different; the effect is much more pronounced in the water medium.

There is a common "cumulative effect" for all three liquids, which is a gradual increase in property change during irradiation. For all liquids there is a "saturation", i.e. the change in measured properties increases within $60 \mathrm{~min}$. Further irradiation is ineffective. At the same time, although further action of the field on water does not lead to changes, the relaxation process begins in alcohols (the property is aimed at its initial value). With regard to the rate of evaporation of liquids, there is a correlation between its change for irradiated systems and the change in surface tension. The deceleration of evaporation corresponds to the value of the surface tension for water and pentanol-1, which increased as a result of field exposure. The acceleration of evaporation corresponds to the reduced surface tension value for propanol-1. These results suggest a greater cohesive interaction in activated water and pentanol and its weakening in propanol. The different effects of the two alcohols can probably be associated either with differences in their structural organization or with the range of studied frequencies. It is possible that different effects can be observed when exposed to a field of higher or lower frequencies.

\section{References}

1 Стехин А.А. Структурированная вода: нелинейные эффекты / А.А. Стехин, Г.В. Яковлева. - М.: Изд-во ЛКИ, 2008. $-320 \mathrm{c}$.

2 Рахманин Ю.А. Вода — космическое явление / Ю.А. Рахманин, В.К. Кондратов. — М.: РАЕН, 2002. — 402 с.

3 Гапочка Л.Д. Воздействие электромагнитного излучения КВЧ- и СВЧ-диапазонов на жидкую воду / Л.Д. Гапочка // Вестн. МГУ. Сер. Физика. Астрономия. - 1994. - Т. 35, № 4. - С. 71-76.

4 Красиков Н.Н. Действие электромагнитного поля на жидкости, осуществляемое без контакта с потенциалозадающими электродами / Н.Н. Красиков, О.В. Шуваева // Журн. физ. хим. — 2000. — Т. 74, № 6. — С. 1133-1135.

5 Lee S.H. et al. Changes in the electrical conductivity, infrared absorption, and surface tension of partially-degassed and magnetically-treated water / S.H. Lee // Journal of Molecular Liquids. — 2013. — Vol. 187. — P. 230-237.

6 Бессонова А.П. Частотная дисперсия физико-химических свойств воды, подвергшейся электромагнитному воздействию / А.П. Бессонова, И.Е. Стась // Изв. вузов. Химия и хим. технол. — 2010. — Т. 53, Вып. 4. — С. $48-50$.

7 Чиркова В.Ю. Изменение когезионных и адгезионных характеристик воды как результат электромагнитного воздействия / В.Ю. Чиркова, Е.А. Шарлаева, И.Е. Стась // Изв. вузов. Прикл. химия и биотехнол. — 2019. — Т. 9(2). — С. $222-231$.

8 Chirkova V.Yu. Boiling temperature and the enthalpy of water vaporization exposed to high frequency electromagnetic field / V.Yu. Chirkova, Ye.A. Sharlayeva, I.Ye. Stas // Bulletin of the university of Karaganda. Chemistry. — 2019. — Vol. 94(2). — P. 51-55.

9 Pang X.F. The changes of macroscopic features and microscopic structures of water under influence of magnetic field / X.F. Pang, B. Deng // Physica B: Condensed Matter. — 2008. — Vol. 403, № 19. — P. 3571-3577.

10 Лаптев Б.И. Структурные изменения в воде и водных растворах электролитов при различных внешних воздействиях / Б.И. Лаптев // Вестн. Томск. гос. ун-та. Сер. Химия. - 2015. — № 1. - С. 13-24.

11 Турсыматова О.И. Изучение влияния электромагнитного излучения на воду и водные растворы методом ядерного магнитного резонанса / О.И. Турсыматова, С.А. Турсынбай // Наука и мир. - 2015. — Т. 1, № 3. - С. 31-33.

12 Сойфер В.Н. Водородная связь в органической химии / В.Н. Сойфер // Соросов. обр. журн. — 1999. - № 52 . C. $58-64$.

13 Неводные растворители / под ред. Т.М. Ваддингтона. - М.: Химия, 1971. - 372 с.

14 Крестов Г.А. Термодинамика процессов в растворах / Г.А. Крестов. - Л.: Химия, 1984. — 272 с.

15 Структурная самоорганизация в растворах и на границе раздела фаз / отв. ред. А.Ю. Цивадзе. — М.: Изд-во ЛКИ, 2008. $-544 \mathrm{c}$.

16 Рабинович И.Б. Влияние изотопии на физико-химические свойства жидкостей / И.Б. Рабинович. — М.: Наука, 1968. $-196 \mathrm{c}$.

17 Справочник химика. - Т. 1. - М.: Химия, 1966. 
18 Курс коллоидной химии. Поверхностные явления и дисперсные системы / Ю.Г. Фролов. — М.: Химия, 1988. - 34 с.

19 Краткий справочник физико-химических величин. - 8-е изд. / под ред. А.А. Равделя и А.М. Пономаревой. - Л.: Химия, 1983. - С. 20, 21.

\author{
И.Е. Стась, С.С. Павлова
}

\title{
Ультражоғары жиіліктегі электромагниттік өрістің ассоцияланған сұйықтықтардың қасиеттеріне әсері
}

\begin{abstract}
Электромагниттік өрістің су, пропанол-1, пентанол-1 сыну көрсеткішіне, булану жылдамдығына және беткі керілуіне әсері зерттелді. Бұл сұйықтықтардың қасиеттері өрістің жиілігіне және оның әсер ету уақытына байланысты екендігі көрсетілген. Өрістің су мен спирттердің құрылымына әсері таңдамалы; олардың қасиеттерінің өзгеруі әр сұйықтық үшін жеке жиіліктерде жүреді. Электромагниттік өрістің жиілігіне байланысты спирттердің булануының баяулауы да, үдеуі де жүреді. Өрістің әсеріне ұшыраған судың булануы барлық зерттелген жиілік диапазонында баяулайды. Пентанол мен судың беткі керілуі артып, пропанол - азаяды. Өріс әсері тоқтағаннан кейін спирттердің қасиеттері бастапқы мәндеріне оралады, ал судың қасиеттері өзгеріссіз қалады. Су мен пропанол-1 бетінің термодинамикалық функциялары беттік керілудің температуралық тәуелділігі негізінде есептеледі. Су үшін беттің жалпы ішкі энергиясы артып, пропанол-1 үшін азаятыны көрсетілді, бұл сулы ортадағы құрылымның беріктеуін және пропанол-1 ортасында молекулааралық өзара әрекеттесудің әлсіреуін көрсетеді.
\end{abstract}

Кілт сөздер: су, пропанол-1, пентанол-1, электромагниттік өріс, жиілік, сыну көрсеткіші, булану жылдамдығы, беттік керілу.

\author{
И.Е. Стась, С.С. Павлова
}

\section{Влияние электромагнитного поля ультравысоких частот на свойства ассоциированных жидкостей}

\begin{abstract}
Изучено влияние электромагнитного поля на показатель преломления, скорость испарения и поверхностное натяжение воды, пропанола-1 и пентанола-1. Было показано, что свойства этих жидкостей зависят от частоты поля и времени его воздействия. Действие поля на структуру воды и спиртов избирательно; изменения их свойств происходят при частотах, индивидуальных для каждой жидкости. В зависимости от частоты электромагнитного поля происходит как замедление, так и ускорение испарения спиртов. Испарение воды, подвергшейся воздействию поля, замедляется во всем исследуемом диапазоне частот. Поверхностное натяжение пентанола и воды увеличивается, а пропанола - уменьшается. После прекращения действия поля свойства спиртов возвращаются к своим исходным значениям, а свойства воды остаются неизменными. Термодинамические функции поверхности воды и пропанола-1 рассчитаны на основе температурной зависимости поверхностного натяжения. Было продемонстрировано, что полная внутренняя энергия поверхности увеличивается для воды и уменьшается для пропанола-1, что указывает на упрочнение структуры в водной среде и ослабление межмолекулярного взаимодействия в среде пропанола-1.
\end{abstract}

Ключевые слова: вода, пропанол-1, пентанол-1, электромагнитное поле, частота, показатель преломления, скорость испарения, поверхностное натяжение.

\section{References}

1 Stekhin, A.A., \& Yakovleva, G.V. (2008). Strukturirovannaia voda: nelineinye effekty [Structured water: Nonlinear effects]. Moscow: Izdatelstvo LKI [in Russian].

2 Rakhmanin, Yu.A., \& Kondratov, V.K. (2002). Voda - kosmicheskoe yavlenie [Water - space phenomenon]. Moscow: RAEN [in Russian].

3 Gapochka, L.D. (1994). Vozdeistvie elektromahnitnoho izlucheniia KVCH- i SVCH-diapazonov na zhidkuiu vodu [The influence of electromagnetic radiation of EHF and SHF-ranges on liquid water]. Vestnik Moskovskoho hosudarstvennoho universiteta. Seriia Fizika. Astronomiia - Bulletin of Moscow State University. Ser. Physics. Astronomy, 35, 4, 71-76 [in Russian].

4 Krasikov, N.N. \& Shuvaeva, O.V. (2000). Deistvie elektromahnitnoho polia na zhidkosti, osushchestvliaemoe bez kontakta s potentsialozadaiushchimi elektrodami [The influence of electromagnetic fields on fluid, carried out without contact with potentialassigned electrodes]. Zhurnal fizicheskoi khimii - Journal of Physical Chemistry, 74, 6, 1133-1135 [in Russian]. 
5 Lee, S.H., et al. (2013). Changes in the electrical conductivity, infrared absorption, and surface tension of partially-degassed and magnetically-treated water. Journal of Molecular Liquids, 187, 230-237.

6 Bessonova, A.P. \& Stas', I.E. (2010). Chastotnaia dispersiia fiziko-khimicheskikh svoistv vody, podverhsheisia elektromahnitnomu vozdeistviiu [Frequency dispersion of the physical and chemical properties of water exposed to the electromagnetic influence]. Izvestiia vuzov. Khimiia i khimicheskaia tekhnolohiia - News of Universities. Chemistry and chemical technology, 53, 4, 48-50 [in Russian].

7 Chirkova, V.Yu., Sharlaeva, E.A., \& Stas', I.E. (2019). Izmenenie kohezionnykh i adhezionnykh kharakteristik vody kak rezultat elektromahnitnoho vozdeistviia [Change of cohesive and adhesive characteristics of water as a result of electromagnetic influence]. Izvestiia vuzov. Prikladnaia khimiia i biotekhnolohiia - News of universities. Applied chemistry and biotechnology, 9(2), 222-231 [in Russian].

8 Chirkova, V.Yu., Sharlayeva, E.A., \& Stas', I.E. (2019). Boiling temperature and the enthalpy of water vaporization exposed to high frequency electromagnetic field. Bulletin of the university of Karaganda. Chemistry, 94(2), 51-55.

9 Pang, X.F., \& Deng, B. (2008). The changes of macroscopic features and microscopic structures of water under influence of magnetic field. Physica B: Condensed Matter, 403, 19, 3571-3577.

10 Laptev, B.I. (2015). Strukturnye izmeneniia v vode i vodnykh rastvorakh elektrolitov pri razlichnykh vneshnikh vozdeistviiakh [Structural changes in water and aqueous electrolyte solutions under various external influences]. Vestnik Tomskoho hosudarstvennoho universiteta. Seriia Khimiia - Bulletin of the Tomsk State University. Chemistry series, 1, 13-24 [in Russian].

11 Tursymatova, O.I., \& Tursynbay, S.A. (2015). Izuchenie vliianiia elektromahnitnoho izlucheniia na vodu i vodnye rastvory metodom yadernoho mahnitnoho rezonansa [Study of the effect of electromagnetic radiation on water and aqueous solutions by the method of nuclear magnetic resonance]. Nauka i mir - Science and World, 1, 3, 31-33 [in Russian].

12 Soifer, V.N. (1999). Vodorodnaia sviaz v orhanicheskoi khimii [Hydrogen bond in organic chemistry]. Sorosovskii obrazovatelnyi zhurnal - Sorosovsk educational Journal, 52, 58-64 [in Russian].

13 Vaddington, T.M. (Ed.) (1971). Nevodnye rastvoriteli [Non-aqueous solvents]. Moscow: Khimiia [in Russian].

14 Krestov, G.A. (1984). Termodinamika protsessov v rastvorakh [Thermodynamics of processes in solutions]. Leningrad: Khimiia [in Russian].

15 Tsivadze, A.Yu. (Ed.) (2008). Strukturnaia samoorhanizatsiia v rastvorakh $i$ na hranitse razdela faz [Structural selforganization in solutions and at the interface]. Moscow: Izdatelstvo LKI [in Russian].

16 Rabinovich, I.B. (1968). Vliianie izotopii na fiziko-khimicheskie svoistva zhidkostei [Effect of isotope on the physical and chemical properties of liquids]. Moscow: Nauka [in Russian].

17 Spravochnik khimika [The chemist's handbook]. (1966). (Vol. 1). Moscow: Khimiia [in Russian].

18 Frolov Yu.G. (1988). Kurs kolloidnoi khimii. Poverhnostnye yavleniia i dispersnye sistemy [Course of colloid chemistry. Surface phenomena and disperse systems]. Moscow: Khimiia [in Russian].

19 Ravdel, A.A., \& Ponomareva, A.M. (Eds.) (1983). Kratkii spravochnik fiziko-khimicheskikh velichin [Quick reference of physical and chemical values]. (8th ed.). Leningrad: Khimiia [in Russian].

\section{Information about authors}

Stas', Irina Evgen'evna - Candidate of Chemical Sciences, Associate Professor of the Department of Physical and Inorganic Chemistry, Altai State University, Lenin Ave., 61, 656049, Barnaul, Russia; e-mail: irinastas@gmail.com

Pavlova, Svetlana Stanislavovna - Candidate of Technical Sciences, Senior Lecturer at the Institute of Oil and Gas, Ugra State University, Chekhov Street 16, 628012, Khanty-Mansiysk, Russia; e-mail: pavlova_ss@mail.ru; https://orcid.org/0000-0001-6137-3968. 